\title{
Feasibility and Design Implications of Fuel Cell Power for Sealift Ships
}

Jing Sun, John Stebe, and Colen Kennell

\begin{abstract}
Hbstract
Fuel cell technologies provide clean and efficient power solutions for both stationary and mobile applications. For shipboard applications, most studies published so far have focused on ship service power or on propulsion power for small vessels with moderate power requirements. Using a military sealift vessel as the platform, this project aims at investigating the implications of implementing fuel cells as the primary power source on a large military cargo ship. A notional solid oxide fuel cell (SOFC) module is proposed and the implications of the technology on fuel savings and machinery arrangements are analyzed. The study shows that, by using a hybrid SOFC-GT (gas turbine) system, high system efficiency can be achieved through combined power-heat-steam generation within the constraints of the given machinery space. The modular features of the fuel cell systems and electrical components are also exploited for flexible machinery arrangements. This paper documents the quantitative analysis of the fuel cell-powered sealift vessel, provides detailed space arrangement schematics for the proposed concept, and identifies the technology gaps and future development opportunities to pursue the next generation of clean and efficient military sealift vessels or commercial cargo ships.
\end{abstract}

\section{Introduction}

Many diverse technology options are currently approaching maturity that affect shipboard power generation, distribution, and utilization. In particular, the integrated power system (IPS) and its associated enabling technologies, including permanent magnet motors, high-speed generators, DC zonal distribution schemes, high-temperature superconductor motors and generators, compact power control components, and fuel cells, are changing the paradigm of conventional machinery plant and ship architecture design. The technology innovations show great promise to meet the new demands that are being placed on ships for higher fuel efficiency, lower environmental impact, and more stringent safety and reliability requirements.

Development of these new technologies has generally been performed under the constraints of the machinery and ship architecture of current technology ships while considering the effects of the individual new technologies. This is particularly true for fuel cells where the principal thrust has been to develop a power plant that is compatible with the footprint of diesel or gas turbine gensets in service today. Fuel cells differ dramatically from diesel and gas turbine-based generators. Special characteristics of this new power generation technology warrant a systematic investigation on shipboard machinery plant arrangement and architecture optimization, especially when the fuel cells are used as the primary power source. The primary goals of this 10-week project are: (a) to evaluate the feasibility of and to understand the requirements for using fuel cells as the primary power source for large ships; (b) to evaluate the impact of the technology on reducing fuel consumption and meeting future environmental objectives; and 
(c) to assess the system integration challenges (in terms of machinery plant configuration and shipboard arrangement optimization) of fuel cells and identify research and development opportunities.

As a case study, the analysis performed in this paper used a military sealift vessel, the Large Medium Speed Roll-on/Roll-off (LMSR), as the platform. This military vessel shares many common features with commercial cargo vessels. The space available on this ship and the accessibility of the information in public domain make it a good candidate to investigate the technology implications of fuel cells on large ships with mega-watts power demands.

This paper documents the results on fuel economy, endurance, and machinery arrangement implications of a notional fuel cell power plant for the sealift vessel considered in this study. Starting with a discussion on fuel cell technology and LMSR shipboard power requirements and arrangement constraints, a notional solid oxide fuel cell (SOFC) system will be defined and its parametric specifications will be delineated. After presenting the results on a quantitative analysis of power plant performance and on schematics of machinery arrangement options, a set of recommendations on research topics for future development will be outlined together with the conclusions.

\section{Fuel Cells for Military Sealift Vessels}

Fuel cells are electro-chemical devices that convert chemical energy of gaseous fuel into electricity without undergoing a combustion process (Larminie and Dicks 2003; Singhal and Kendall 2002; Sammes et al. 2005). The high efficiency and low emissions associated with the devices make them very attractive for both stationary and mobile applications. As such, they are considered as potential alternative power solutions to meet future shipboard power demands with low environmental impact. Many studies on marine fuel cell applications have been published (Fontell et al. 2004; Allen et al. 1998; Tsourapas et al. 2004, 2008; Mueller et al.
2008; Reenaas 2005) and several successful technology demonstrations have been showcased (Collins 2006; Hoffman 2007; FuelCell Energy 2009; European Commission Transportation Research 2009; Zemships 2009; Douglass and Partos 2003; Hammerschmidt 2006) by the academic research and industrial or development communities. Among them, the fuel cell ship service system sponsored by the Office of Naval Research (Collins 2006; Hoffman 2007; FuelCell Energy 2009), the Methapu and Fellowship under the European Commission (European Commission Transportation Research 2009) are representative examples.

Most of the fuel cell studies and demonstration programs target auxiliary power applications, with some exceptions such as the submarine program (Hammerschmidt 2006) and small pleasure boats (Zemships 2009) where the fuel cells are used for propulsion. In this study, however, the research is focused on exploring the fuel cell as the primary power source for large highpower vessels with moderate space limitations (such as the military sealift vessels) in order to understand the technology potentials and limitations. While it is recognized that today's stateof-the-art fuel cell technology does not meet the requirements specified in this paper and substantial technology gaps exist in making the technology feasible for the targeted applications, the research is aiming at developing design concepts for ships 15-20 years in the future that will meet the energy conservation and environmental protection mission of the Navy and the marine industry.

\section{LMSR SHIP CHARACTERISTICS AND PRINCIPAL CONSTRAINTS}

For this feasibility study, a large sealift vessel of US Military Sealift Command for prepositioning operation, in this case the LMSR as shown in

Figure $\mathbf{1}$, is considered. The key characteristics of the vessel are listed in Table $\mathbf{1}$ (US Military Sealift Command 1998; M. Touma 2009, personal communication). This large vessel provides a total cargo space of over $400,000 \mathrm{ft}^{2}$, larger than eight full size football fields. To power the ship 
up to 24 knots while supporting all the auxiliary machinery and service loads, a total power of $64 \mathrm{MW}$ is installed as shown in Table 2. This power is supplied by medium speed diesel engines or gas turbines (for propulsion) and medium speed diesel generator sets (for auxiliary power). Major loads onboard the ship are listed in Table 3. The propulsion load, as a function of vessel speed, is shown in Figure 2, while the auxiliary loads for different operating modes are given in Figure 3, where power consumptions for different load groups are shown by different colors. In addition, two boilers are installed onboard the ship to meet the steam demands for distillation plants, oil purification needs, etc. Under a typical summer condition, the required steam load is about $3,355 \mathrm{~kg} / \mathrm{h}$ for underway operation.

For this study, the hull form of the LMSR is kept the same and the design and analysis are performed with the constraints of the current engine room configuration, propulsion shaft lines and exhaust stack locations. The current engine room spans three decks and 14 frames and is approximately $126 \mathrm{ft}$ long and $100 \mathrm{ft}$ wide. Figure 4 shows the vessel hull with the engine room, propulsion shafts, and exhaust stack. It is also assumed that the auxiliary loads to be served by the new power plants will remain the same as those on the current LMSR, except those associated with the propulsion power plants. The three voltage level system architecture (high, medium, and low voltage) will be maintained for the fuel cell-powered system, except that the high-voltage system will be DC as opposed to AC and the transformers will be replaced by power converters.

\section{TABLE 1: General Characteristics of LMSR}

\begin{tabular}{lc} 
Hull form & Monohull \\
\hline Cargo type & Roll-on/roll-off \\
\hline Length overall & $290(\mathrm{~m})$ \\
\hline Beam & $32(\mathrm{~m})$ \\
\hline Draft & $10.5(\mathrm{~m})$ \\
\hline Service speed & $24(\mathrm{knots})$ \\
\hline Displacement (loaded) & $62,790(\mathrm{LT})$
\end{tabular}

LMSR, larģe medium speed roll-on/roll-off.

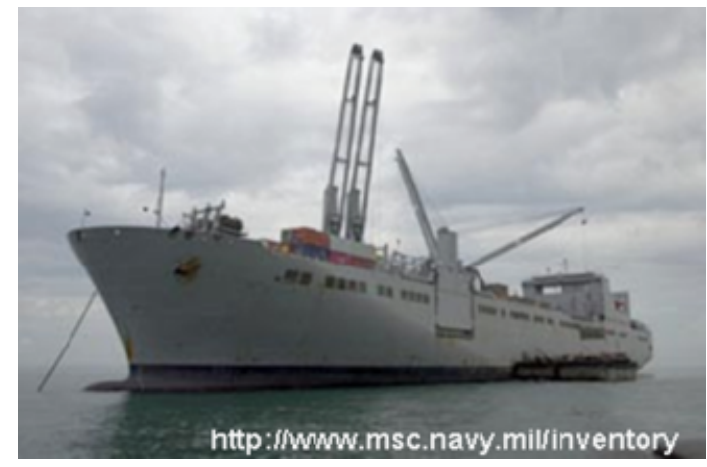

Figure 1: USNS Seay

The power requirements, coupled with the space and weight constraints of the shipboard application, represent the main challenges in implementing fuel cell power for the vessel under consideration. Based on publicly accessible information, there is no fuel cell system available that can provide $>1 \mathrm{MW}$ power with the power density required by the LMSR shipboard applications. Data and information on integrated fuel cell power systems are generally guarded as proprietary and rarely available in the public domain. For this study, we propose a notional fuel cell system based on publicly accessible information and technology trend projection. Assumptions are made for the power system size, density, and performance with rationales given wherever they are applicable. The specifications of the notional system can also serve the purpose for providing requirements for future

$\begin{aligned} & \text { TABLE 2: Power Plants on the Baseline } \\
& \text { Vessel }\end{aligned}$
\begin{tabular}{ll} 
Propulsion & $4 \times 12 \mathrm{MW}$ medium speed \\
& diesel engine + gear box or \\
& $2 \times 24 \mathrm{MW}$ gas turbine + \\
& gearbox \\
& $4 \times 3.5 \mathrm{MW}$ diesel \\
\hline Ship service diesel engine & $1 \times 1.6 \mathrm{MW}$ \\
\hline Emergency diesel generator & $63.6 \mathrm{MW}$ \\
\hline Total installed power &
\end{tabular}

\section{TABLE 3: Major Loads on the Baseline} Vessel

\begin{tabular}{ll} 
Propulsion & $2 \times 24 \mathrm{MW}$ \\
\hline Bow thruster & $2 \times 1 \mathrm{MW}$ \\
\hline Cargo handling & $5.2 \mathrm{MW}$ \\
\hline Air conditioning & $1.2 \mathrm{MW}$ \\
\hline
\end{tabular}


Figure 2: Propulsion Power Demand as a Function of Vessel speed

Figure 3: $L M S R$ Electrical System Loads in Different Operating Modes
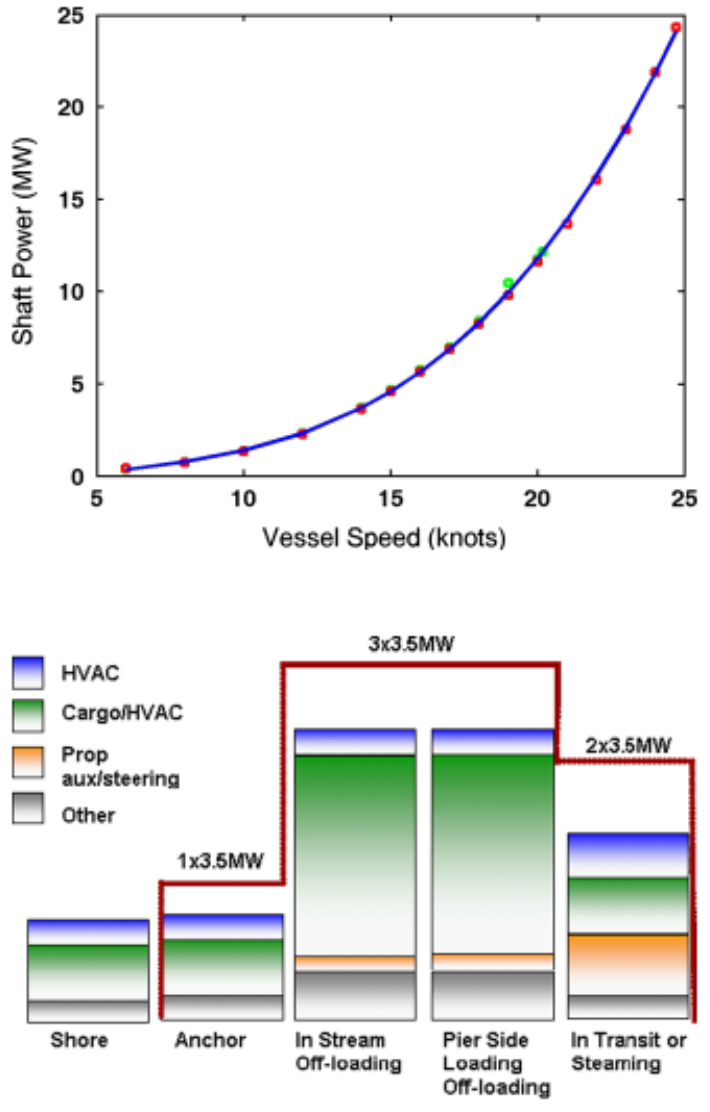

shipboard fuel cell system development, as well as for ship designers in evaluating the technology suitability.

\section{Proposed Notional Fuel Cell Power Plants for LMSR}

In this section, a notional hybrid SOFC-GT power plant is proposed and the combined heat-power-steam (CHPS) generation is recommended for the power system to meet the LMSR power demands. The system configuration and

Figure 4: $L M S R$ Engine Room, Propeller Shafts, and Exhaust Stack

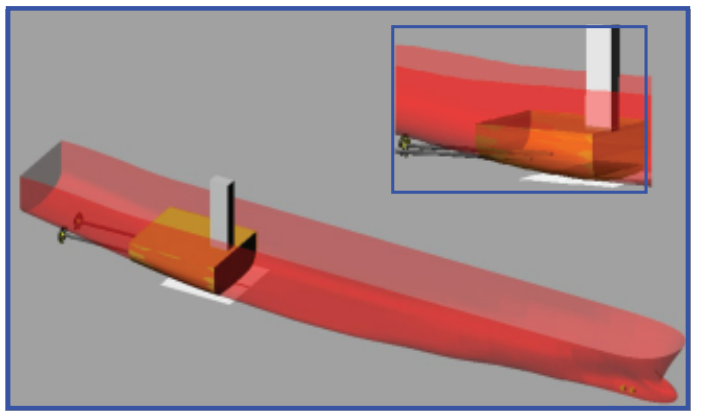

key features of the proposed power system are described in the following.

\section{NOTIONAL SOFC MODULE AND HYBRID SOFC-GT ENGINE}

Given the nature of the shipboard loads to be served by the power plants, the future fuel cell power systems should have the following characteristics which, in turn, will dictate the decision on the fuel cell technology and configuration selection:

High-power density for large-scale power application (mega-watts level);

- Simple reforming and fuel processing requirements;

Capability of CHPS generation to support electrical, heat, and steam loads that coexist onboard the ship.

These requirements naturally lead to high-temperature fuel cell technologies, among which the SOFCs are considered as the most promising. High-temperature fuel cells offer higher system efficiency and higher power density, compared to low-temperature fuel cell technologies (Larminie and Dicks 2003; Singhal and Kendall 2002; Stambouli and Traversa 2002). They also allow more flexibility in their fueling strategy, thanks to the internal reforming capability offered by hightemperature operation. With the high-quality exhaust heat energy, CHPS generation can be achieved by integrating the SOFC power plants with gas turbine or steam power plants to achieve higher efficiency for the combined cycle (Mueller et al. 2008; Reenaas 2005; Tsourapas et al. 2005). Because the ship machinery design and engineering community is accustomed to high-temperature power plants onboard, the high-temperature operation of SOFC presents more opportunities than challenges for shipboard application.

We therefore propose a hybrid SOFC-GT system as the power module for the fuel-cell-powered cargo ship. The notional SOFC system module, which will be the building block for the proposed power plant, has an electrical output 
of $5 \mathrm{MW}$ with efficiency of $50 \%$ and volumetric density of $40 \mathrm{~W} / \mathrm{L}$. We use four SOFC modules and one gas turbine-generator set to make one hybrid SOFC-GT engine, which will produce a total electrical net output power of $24 \mathrm{MW}$ for the combined power plant. The schematic diagram of the hybrid SOFC-GT engine is shown in Figure 5 and the key parameters in Table 4.

As shown in Figure 5, a catalytic burner is connected to the exhaust of the SOFC system to convert any fuel left in the SOFC anode exhaust into heat energy. This burner can also be used for the start-up operation to speed up the system warm-up process. The high-temperature SOFC exhaust, with the temperature further elevated by the burner, will then power the turbine to recuperate the high-quality heat energy in the exhaust. The turbine will drive the compressor, through a mechanical shaft, to deliver the air to the SOFC modules, thereby saving the auxiliary power that is needed to drive the air compressor and increasing the total system efficiency. The turbine also drives a generator that is connected to the same mechanical shaft to generate additional electrical power. This hybrid SOFC engine with a gas turbine as the bottoming cycle boosts the efficiency of the total system from $50 \%$ to $60 \%$ and total power from 20 to $24 \mathrm{MW}$.

The parameters of the SOFC and turbine/compressor (shown in Table 4) are chosen to achieve 1:5 power split ratio between the generator and SOFC while considering several major trade-offs among different competing requirements and constraints. For example, the fuel utilization will affect the power split ratio between SOFC and gas turbine. In general, high fuel utilization will lead to high system efficiency, as more power will be generated by the more efficient SOFC plant with higher fuel utilization. However, too high fuel utilization could lead to local fuel starvation in SOFC and high concentration loss. A fuel utilization of $85 \%$ reflects a reasonable trade-off between efficiency and operational safety consideration. Similarly, air utilization can affect power generation in both the SOFC

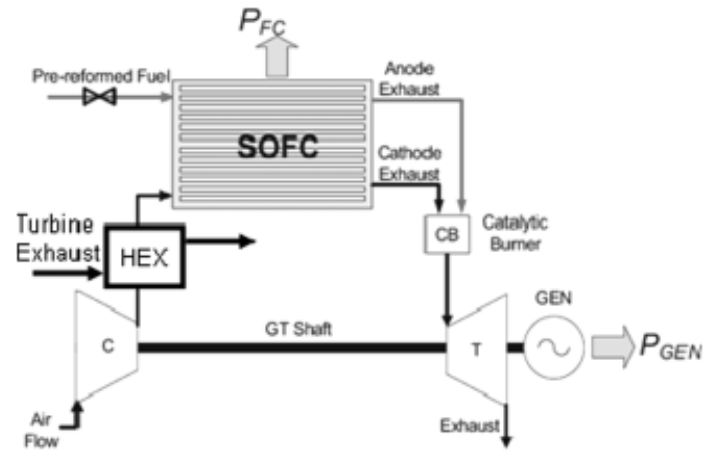

Figure 5: Schematic of the Hybrid SOFCGT System and generator. Because air is used as coolant in the SOFC, too high air utilization will lead to insufficient cooling in SOFC and reduced generator power because of the reduced exhaust flow rate. On the other hand, low air utilization will require too much airflow, causing increased compressor power consumption and parasitic loss. The value of $25 \%$ shown in Table 4 represents the optimal trade-off after evaluating these different parameter effects on the system efficiency and power split ratio.

It should be pointed out that the power density required by the notional system is not achievable with current state-of-the-art SOFC technologies. However, it represents our best estimate of what is required for the fuel cell-powered LMSR and what might be achievable in the next 15-20 years. In predicting the power density of the SOFC system, it is also assumed that very low sulfur fuel will be available worldwide after 2020 and on-board desulfurization will not be

\section{TABLE 4: Principal Parameters of SOFC Power Plant}

\begin{tabular}{ll} 
SOFC module & \\
\hline Output power & $5 \mathrm{MW}$ \\
\hline Efficiency & $50 \%$ \\
\hline Fuel utilization & $85 \%$ \\
\hline Air utilization & $25 \%$ \\
\hline Air/fuel inlet temperature & $600{ }^{\circ} \mathrm{C}$ \\
\hline Turbine/compressor & \\
\hline Compressor efficiency & $85 \%$ \\
\hline Turbine efficiency & $80 \%$ \\
\hline Pressure ratio & $1: 4$ \\
\hline Generator power & $4 \mathrm{MW}$ \\
\hline
\end{tabular}

SOFC, solid oxide fuel cell. 


\section{TABLE 5: Comparison of Fuel Cell with Diesel and Gas Turbine Propulsion Options}

\begin{tabular}{lccc} 
& $\begin{array}{c}\text { Hybrid } \\
\text { SOFC-GT }\end{array}$ & $\begin{array}{c}\text { Medium } \\
\text { Speed Diesel }\end{array}$ & $\begin{array}{c}\text { Gas } \\
\text { Turbine }\end{array}$ \\
\hline Power level (MW) & $4 \times 5+4$ & $12 \times 2$ & 24 \\
\hline Efficiency (\%) & 60 & 45 & 37 \\
\hline Volumetric power density $(w / i)$ & 45 & 44 & 340 \\
\hline Gravimetric power density $(w / \mathrm{kg})$ & 75 & 59 & 5,107 \\
\hline Specific air flow $(\mathrm{kg} / \mathrm{MW})$ & 6.9 & 7.1 & 10.3 \\
\hline
\end{tabular}

SOFC, solid oxide fuel cell; GT, gas turbine.

necessary. This assumption simplifies the fuel processing requirements and justifies the reduced SOFC volume. Other references, such as the ONR notional HT-PEM system (which assumes a power density of $35 \mathrm{~W} / \mathrm{L}$ ) (Hoffman 2007; H. Edward 2009, personal communication) and the fuel cell and stack power performance, are also used in projecting this future power density required for LMSR.

To put it all in perspective, the proposed power plant is compared with its counterpart diesel and gas turbine engines in Table 5 in terms of their key parameters. One can see that the hybrid SOFC-GT has a substantial efficiency advantage over the other two power options. For volumetric power density, the gas turbine will remain as the best option for space constrained applications. However, the LMSR is not space limited in that sense, and therefore fuel cells, which have similar volumetric power density to a medium speed diesel power plant, will be an attractive option. Another important consideration is the intake and exhaust requirements. This analysis shows that the specific air consumption of the proposed fuel cell power plant will be slightly lower than the diesel plant and substantially lower than gas turbine plant. This implies that

\section{TABLE 6: Steam Loads (in kg/h) for Diesel and Fuel Cell-Powered LMSR}

\begin{tabular}{lccccccc} 
& \multicolumn{3}{c}{ Summer Condition } & & \multicolumn{3}{c}{ Winter Condition } \\
\cline { 2 - 4 } \cline { 7 - 8 } & Underway & In Port & Anchor & & Underway & In Port & Anchor \\
Diesel & 3,355 & 2,525 & 3,877 & & 5,382 & 4,776 & 5,876 \\
\hline Fuel cell & 2,946 & 1,470 & 2,946 & & 4,581 & 3,073 & 4,423 \\
\hline
\end{tabular}

LMSR, large medium speed roll-on/roll-off. the exhaust stack and air duct system of the current diesel LMSR do not have to be altered to accommodate the fuel cell power plant. If we replace the gas turbine with the fuel cell power plant, then the exhaust stack can be downsized by about $30 \%$.

\section{COMBINED POWER AND STEAM GENERATION}

The current LMSRs have two separate boilers to meet the steam generation requirements, such as the distillation plant, HVAC humidifier, oil purification, etc., as shown in Table 6. For a typical summer condition, a total steam output of $3,355 \mathrm{~kg} / \mathrm{h}$ is required to support all the steam loads, which will consume about $234 \mathrm{~kg} / \mathrm{h}$ of fuel. For the fuel cell-powered LMSR, some of the steam loads, such as the engine lubrication oil purifiers and jacket water preheat systems, will be removed, thereby reducing the steam loads. The high-temperature exhaust gas (about $850^{\circ} \mathrm{C}$ ) from SOFC will be a good energy source for steam production. Therefore, the boilers will be eliminated from the new power plant configuration, and will be replaced by a $5 \mathrm{MW}$ SOFC plant bottoming cycled with a steam plant.

\section{LMSR IPS POWER PLANT CONFIGURATION}

To meet the total LMSR power demands with the fuel cell as the primary power source, the following power plant configuration, based on the notional SOFC module and hybrid SOFC-GT engine, is proposed. First, the fuel cell-powered LMSR will naturally render the ship for an IPS and electric propulsion. Given the power demand profile shown in Figures 2 and 3, it can be seen that the peak power demands for the ship service and propulsion systems are naturally exclusive of each other. Therefore, combining the ship service and propulsion power systems into an integrated power network can reduce the total installed power requirement. For this study, an IPS with the total installed power of $53 \mathrm{MW}$ is the target, plus an emergency diesel generator (of $1.6 \mathrm{MW}$ ). The net reduction of $10 \mathrm{MW}$ in installed power reflects the savings due to the IPS and the CHPS generation of the proposed SOFC system. Any future 


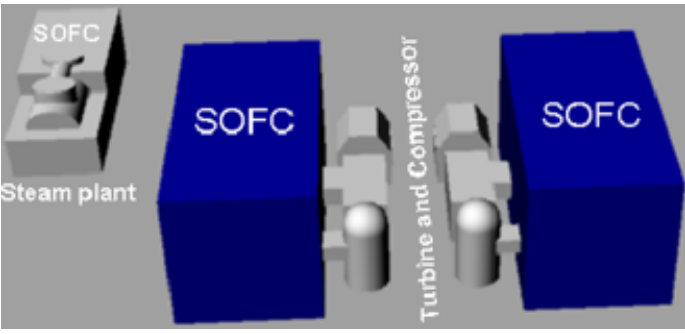

Figure 6: Power Plants for Fuel Cell-Powered LMSR

improvement in propulsion system and ship hull design may reduce this even further.

The proposed shipboard power system will consist of two SOFC-GT engines (20 MW SOFC+4 MW GT/GEN) and one small SOFC (5 MW) with a steam plant as the bottoming cycle to support all the steam loads, as illustrated by Figure 6 . The two SOFC-GT engines, together with the motors, motor drivers, power electronics converters, and switchboards, are installed in the main engine room. The small power plant can be housed in the engine room with the hybrid SOFC-GT engines, or it can be located at the higher deck where it can be placed closer to the cargo handling equipment and cargo space AC systems (two of the biggest auxiliary loads on the ship). The latter arrangement will allow us to place the power closer to the point-of-load to take advantages of distributed power generation at a small expense of a more complicated fuel handling system. The distributed power plant configuration also provides better survivability in case of damage.

The relative sizing of the large hybrid SOFC-GT engine and the small SOFC power plant was determined by considering the SOFC power turndown ratio. Fuel cell systems have relatively flat efficiency curve over a wide range of operating conditions, except at very low load (below $20 \%$ ). The power plant combination selected will make it possible to operate all the fuel cell modules above $20 \%$ load at any operating condition, as shown in Figure 7, where the power split among individual power systems for any given demanded power is illustrated.

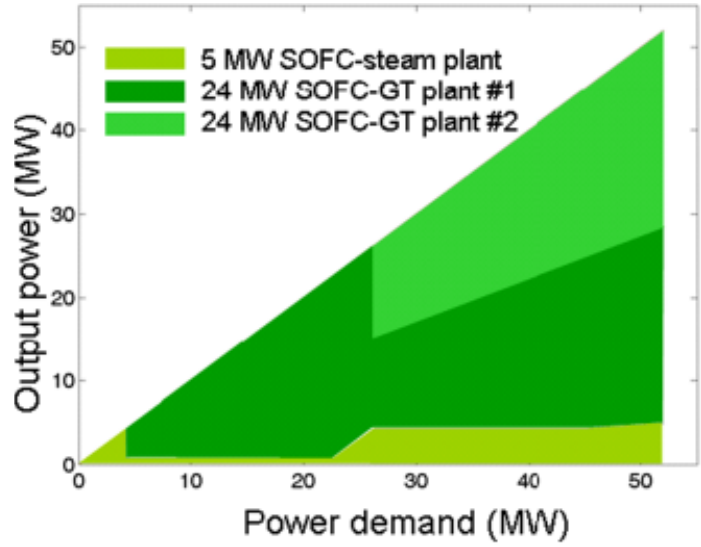

Figure 7: Example of Power Split among Three SOFC Power Plants for Any Given Power Demand

\section{Power System Analysis}

Thermodynamic cycle analysis was performed for the proposed power plant to verify the energy balance and temperature constraints to validate the proposed concept. For a typical operating condition with the ambient temperature at $27^{\circ} \mathrm{C}$, the temperature at various points in the system and power outputs of the SOFC and generator are shown in Figure 8. The analysis confirms that the assumptions made on the efficiencies of the SOFC, compressor and turbine, as well as the fuel and air utilization, are reasonable and lead to the desired temperature gradient within the system and favorable power split ratio between the SOFC and turbine generator. It also shows that sufficient exhaust heat will be available to provide the cathode air preheating needs.

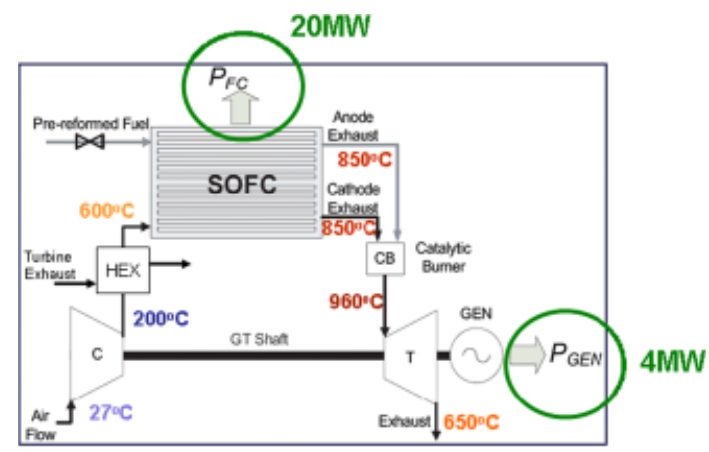

Figure 8: Temperatures and Power Outputs of the Hybrid SOFC-GT Engine 
Analysis was also performed to evaluate the sensitivity of the system outputs with respect to variations in inputs and component parameters. Air inlet temperature, compressor and turbine efficiency, air and fuel utilization were varied from their nominal values to check the off-design conditions for output power performance. In this analysis, attention was also paid to possible violations of two constraints: insufficient preheating energy if the turbine exhaust temperature is too low (below $625^{\circ} \mathrm{C}$ ), possible over-heating in the burner (burner temperature above $1,200^{\circ} \mathrm{C}$ ). The results are summarized in Tables 7-9.

For all the conditions evaluated, the net output power change (out of $24 \mathrm{MW}$ ) will be no more than $2.0 \%$, indicating a rather robust design. It should be pointed out that if the turbine efficiency is too high, the exhaust temperature might be too low to support air preheating. If the fuel utilization is too low, the burner might be exposed to over-heating conditions. As a distinctive feature of the integrated system, the components of the hybrid SOFC-GT are closely coupled and interactive, which dictates that the design and analysis should focus on component interactions and system level performance in optimization and component sizing.

\section{Fuel Saving Analysis}

Quantitative analysis for fuel savings was performed for different missions and for different operating modes. Furthermore, endurance of the fuel cell-powered vessel, measured in terms of distance traveled at peak speed, is also compared with those powered by diesel and gas turbine power plants. For the fuel saving analysis, power plant

\section{TABLE 7: Sensitivity of the Power Output to Inlet Air Temperature Changes}

\begin{tabular}{lrrr}
$T_{\text {inlet }}\left({ }^{\circ} \mathrm{C}\right)$ & 0 & 27 & 37 \\
\hline$P_{\text {gen }}(\mathrm{kW})$ & 4,650 & 4,023 & 3,790 \\
\hline$\delta P_{\text {net }}(\%)$ & 1.7 & 0 & -0.6 \\
\hline$T_{\text {cmp }}\left({ }^{\circ} \mathrm{C}\right)$ & 156 & 200 & 214 \\
\hline
\end{tabular}

\section{TABLE 8: Sensitivity of the Output Power to Compressor and Turbine Efficiency Changes}

\begin{tabular}{lcrc}
$\eta_{\text {cmp }}(\%)$ & 80 & 85 & 90 \\
\hline$P_{\text {gen }}(\mathrm{kW})$ & 3,578 & 4,023 & 4,756 \\
\hline$\delta P_{\text {net }}(\%)$ & -1.2 & 0 & 2.0 \\
\hline$T_{\text {cmp }}\left({ }^{\circ} \mathrm{C}\right)$ & 210 & 200 & 180 \\
$\eta_{\text {trbn }}(\%)$ & 75 & 80 & 85 \\
\hline$P_{\text {gen }}(\mathrm{kW})$ & 3,336 & 4,023 & 4,710 \\
\hline$\delta P_{\text {net }}(\%)$ & -1.9 & 0 & 1.9 \\
\hline$T_{\text {trbn }}\left({ }^{\circ} \mathrm{C}\right)$ & 670 & 650 & 630
\end{tabular}

efficiencies for diesel propulsion engines, diesel auxiliary generators, and gas turbine propulsion engines were used based on available information, as shown in Figure $\mathbf{9}$. For the fuel cell power plant, a constant efficiency of $50 \%$ was assumed for conditions above $20 \%$ load. For economic analysis, only the fuel cost was considered in this study. Other costs or benefits, such as refueling costs and savings, were not included in this initial estimation and they should be considered for further in-depth analysis in the future.

\section{OPERATING MODE ANALYSIS}

The vessels under consideration have a typical operational profile (percentage of operating

\section{TABLE 9: Sensitivity of the Output Power to Changes in Air and Fuel Utilization}

\begin{tabular}{lccc} 
Air utilization & $20 \%$ & $25 \%$ & $30 \%$ \\
\hline$P_{\text {gen }}(\mathrm{kW})$ & 4,137 & 4,023 & 3,947 \\
\hline$\delta P_{\text {net }}(\%)$ & 0.5 & 0 & -0.3 \\
\hline$T_{\text {tc }}\left({ }^{\circ} \mathrm{C}\right)$ & 824 & 850 & 932 \\
\hline$T_{\text {trbn }}\left({ }^{\circ} \mathrm{C}\right)$ & 593 & 650 & 703 \\
\hline Fuel utilization & $80 \%$ & $85 \%$ & $90 \%$ \\
\hline$P_{\text {gen }}(\mathrm{kW})$ & 4,313 & 4,023 & 3,733 \\
\hline$\delta P_{\text {net }}(\%)$ & 1.2 & 0 & -1.2 \\
\hline$T_{\text {brn }}\left({ }^{\circ} \mathrm{C}\right)$ & 1,050 & 977 & 900 \\
\hline$T_{\text {trbn }}\left({ }^{\circ} \mathrm{C}\right)$ & 674 & 650 & 626
\end{tabular}




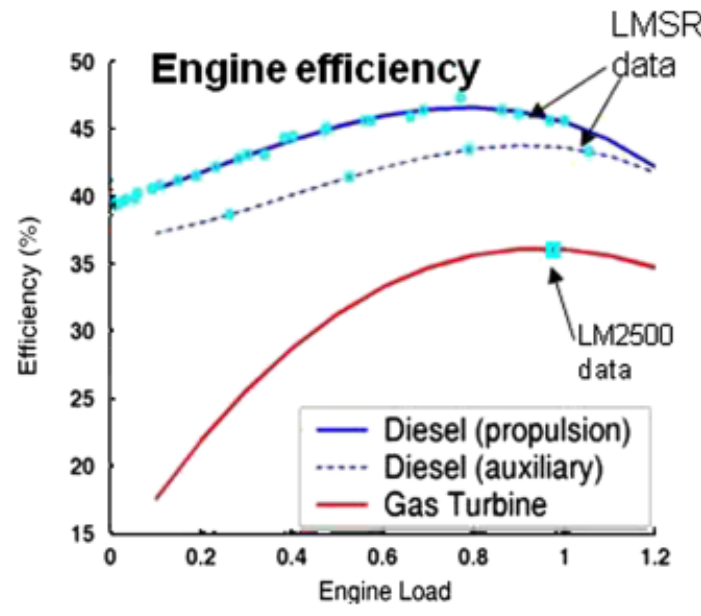

Figure 9: Power Plant Efficiencies Used in Fuel Consumption Calculation

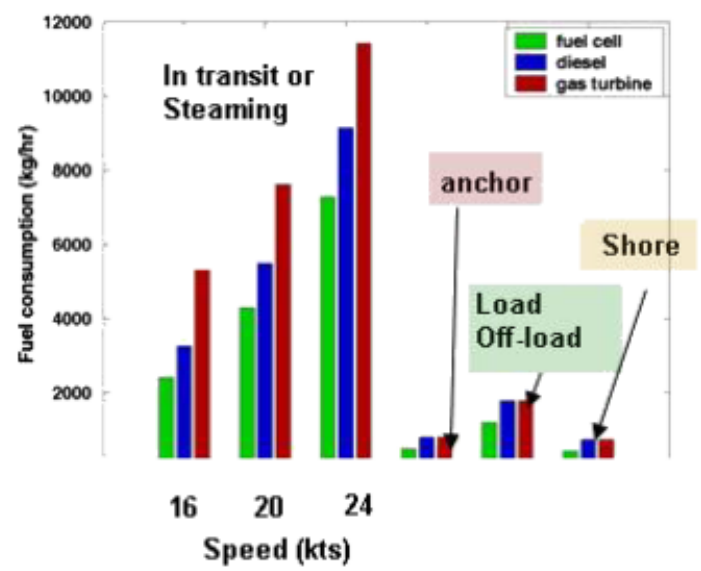

In transit or

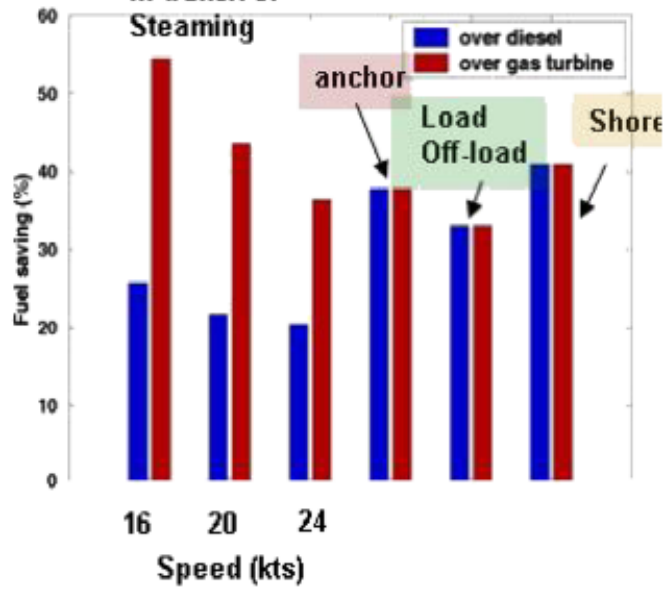

Figure 10: Fuel Consumption for Different Operating Modes hours) given as follows:

$$
\begin{aligned}
& \text { Shore: } \sim 5 \% \\
& \text { Anchor: } \sim 79 \% \\
& \text { Pier side load/offload: } \sim 2 \% \\
& \text { In transit: } \sim 6 \% \\
& \text { Steaming exercise: } \sim 8 \%
\end{aligned}
$$

For each operating mode, fuel consumption is calculated for the three different power plants and results are shown in Figure $\mathbf{1 0}$ in the top chart and the relative savings of the fuel cell-powered LMSR over diesel and gas turbine are shown in the bottom chart. Incorporating the information on the time spent in each operating mode, the aggregated annual fuel consumption is calculated and shown in Figure $\mathbf{1 1}$ in terms of both total fuel spent and the dollar amount, where the dollar amount is calculated using the commercial fuel price at the end of August 2009
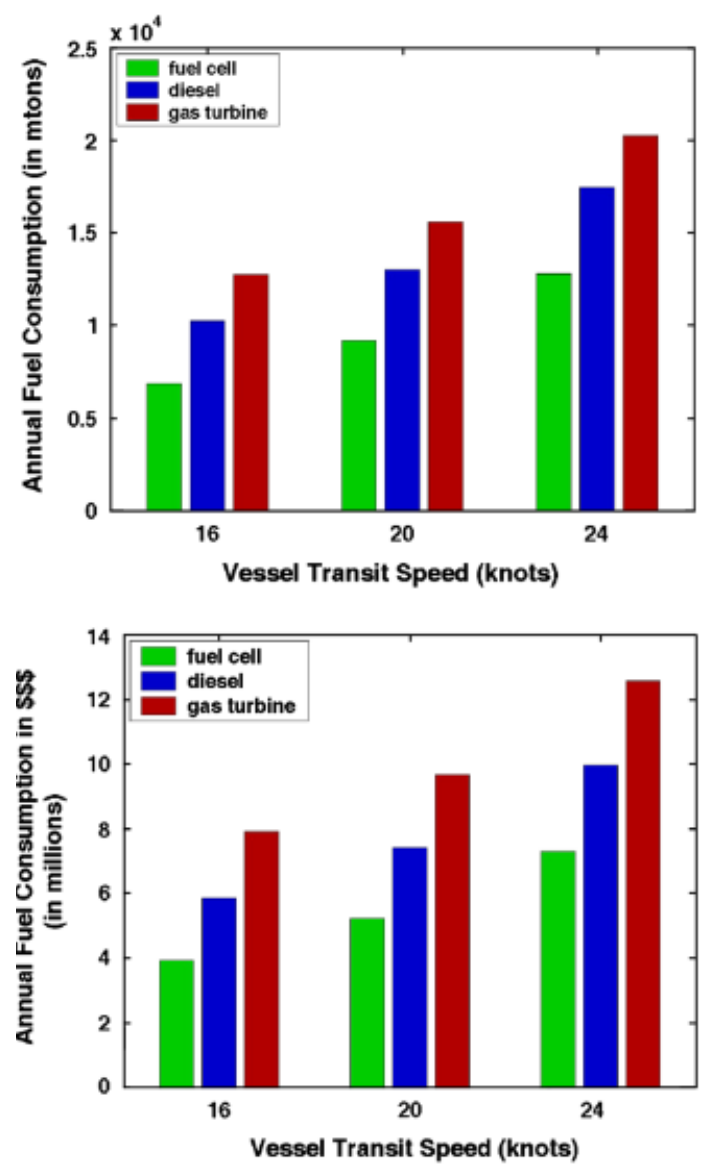

Figure 11: Annual Fuel Consumptions for Three Different Power Plants 
TABLE 10: Description of Mission Scenarios

\begin{tabular}{|c|c|c|c|c|}
\hline & \multirow[b]{2}{*}{ Mission Description } & \multicolumn{3}{|c|}{ Mission Span (Days and Distance Traveled) } \\
\hline & & 16 knots & 20 knots & 24 knots \\
\hline \multirow[t]{2}{*}{ Mission scenario \#1 } & 4 days loading, $8,600 \mathrm{~nm}$ transit, & 60 days & 51 days & 45 days \\
\hline & $\begin{array}{l}4 \text { days unloading, } 7 \text { days anchor, } \\
\text { then return without cargo }\end{array}$ & $17,200 \mathrm{~nm}$ & $17,200 \mathrm{~nm}$ & $17,200 \mathrm{~nm}$ \\
\hline \multirow[t]{2}{*}{ Mission scenario \#2 } & 4 days loading, $8,600 \mathrm{~nm}$ transit, & 44 days & 39 days & 35 days \\
\hline & $\begin{array}{l}\text { 4-days unloading, } 7 \text { days anchor, } \\
3 \text { days reloading, then transit } \\
1,200 \mathrm{~nm} \text { to the next destination }\end{array}$ & $9,800 \mathrm{~nm}$ & $9,800 \mathrm{~nm}$ & $9,800 \mathrm{~nm}$ \\
\hline \multirow[t]{2}{*}{ Mission scenario \#3 } & Independent steaming exercise for & 5 days & 5 days & 5 days \\
\hline & 5 days & $1,920 \mathrm{~nm}$ & $2,400 \mathrm{~nm}$ & $2,880 \mathrm{~nm}$ \\
\hline
\end{tabular}

(US\$560/ton for MDO and US\$620/ton for MGO). The speed shown on Figure 11 is the corresponding speed used whenever the vessel is in transit or doing an independent steaming exercise. A few points to note:

High relative savings are achieved at port side for the diesel-powered LMSR and in transit or steaming for the gas turbine system. This is mainly due to the fact that for diesel-powered LMSRs, there is an option of using one engine per shaft at low speed to reduce the losses in efficiency at part loads.

Substantial savings in fuel consumption are noted for the fuel cell, and they directly translate to reduced fuel cost (US\$2M over diesel and US\$4M over gas turbine).

Almost a tankful of fuel can be saved over the year, which will also lead to significant refueling saving.

\section{FUEL CONSUMPTION ANALYSIS FOR DIFFERENT MISSION SCENARIOS}

Three different mission scenarios are considered, whose descriptions are given in Table 10. Fuel consumption for those missions is summarized in Figure 12. One can see that consistent fuel savings are achieved for all mission scenarios considered. Roughly speaking, fuel cells can save $>20 \%$ and $50 \%$ over their diesel and gas turbine counterparts, respectively. More detailed analysis reveals that the relative saving over the gas turbine-powered system is more sensitive to the vessel speed, when compared with the saving over the diesel-powered system. For example, as the speed changes from 16 to 24 knots, the relative fuel saving of the fuel cell-powered vessel over the gas turbine changes from $53.4 \%$ to $35.6 \%$, while when compared with diesel, the saving only changes from $22.8 \%$ to $18.2 \%$.

\section{ENDURANCE ANALYSIS}

Mission endurance in this analysis is measured by the distance traveled with $90 \%$ of the full fuel capacity at the peak speed of 24 knots. Note that the diesel and gas turbine-powered LMSRs have different tank sizes to achieve the same endurance. The calculation for the fuel cell-powered vessel was performed for two different tank sizes so that they can be compared with the corresponding power plants. The results are shown in Figure 13. The analysis shows that the fuel cell-powered LMSR has an endurance advantage of $25 \%$ and $57 \%$ over diesel and gas turbine system, respectively. Namely, with the same tank size, the fuel cell can extend the range of the diesel-propelled LMSR by $25 \%$ and the range of the gas turbine-powered LMSR by $57 \%$ at full speed. Or, if designed for the same endurance, the fuel tank size can be reduced for the diesel LMSR by $25 \%$ and for the gas turbine by $57 \%$ if the proposed notional fuel cell systems are used.

The range and days for continuous transit operation were also calculated for other speeds and results are included in Figure 13. One can see that the benefits of the FC-LMSR are even 

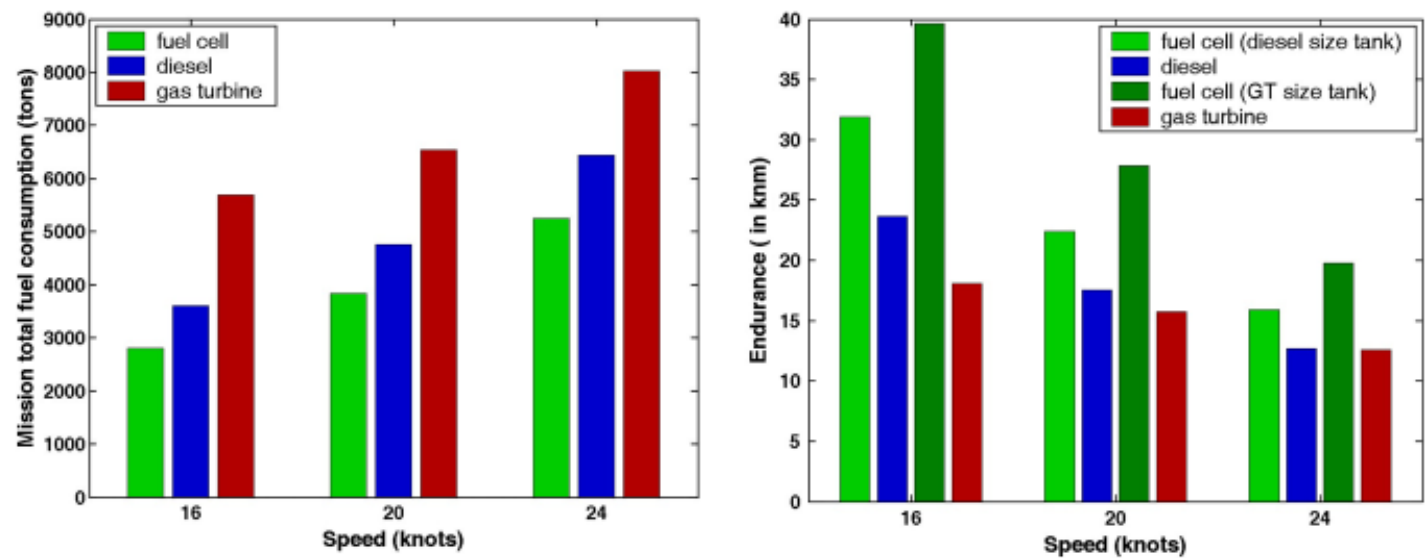

Figure 13: Comparison of Endurance for the Fuel Cell-Powered LMSR with the Diesel and Gas TurbinePowered LMSRs in Terms of Distance and Days Traveled by the Vessel with Full Tank of Fuel
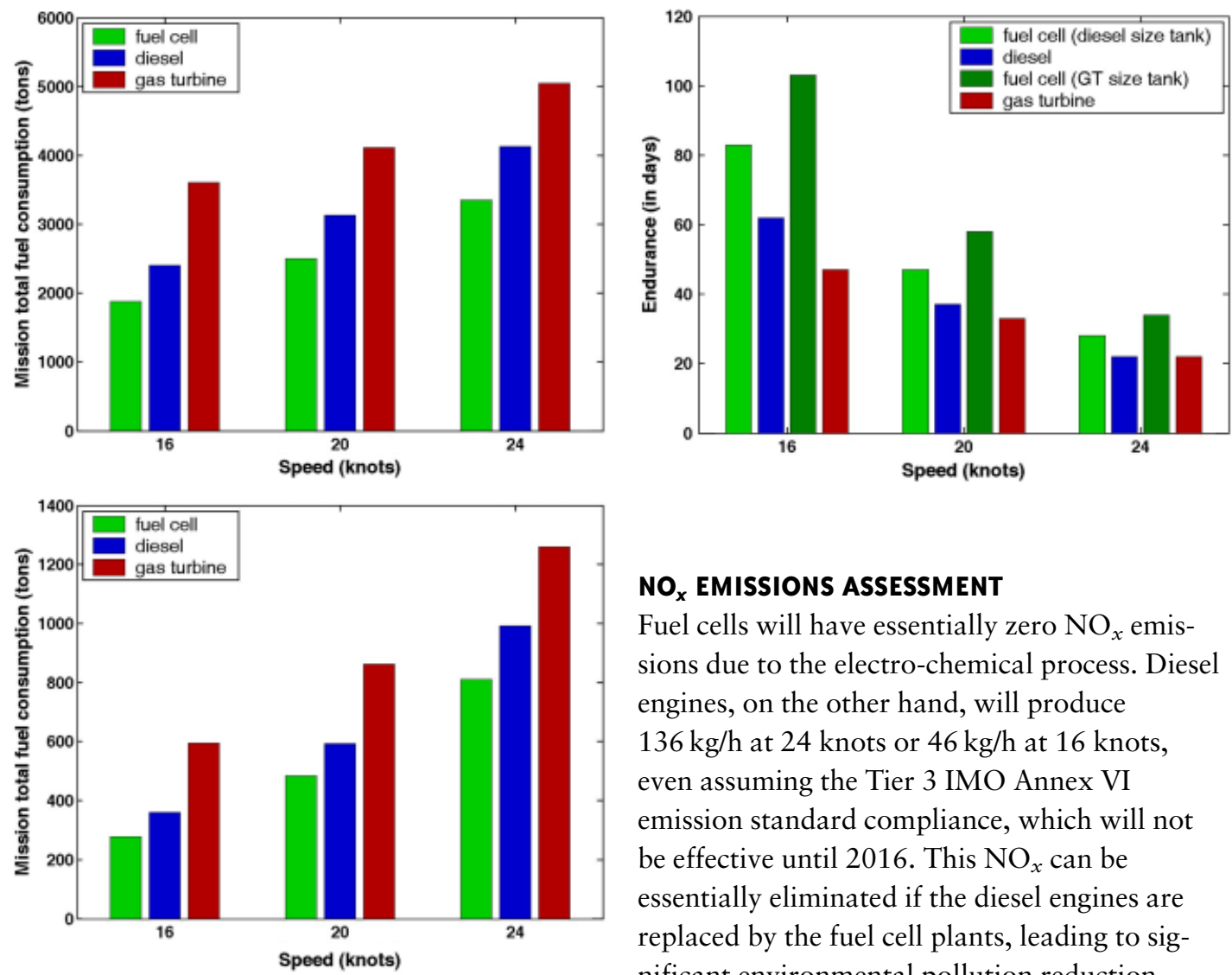

Figure 12: Fuel Consumptions for Three Different Mission Scenarios and Three Power Plants

more pronounced at reduced speed. For example, if operated at 16 knots, the distance traveled by the LMSR with $90 \%$ of a full tank of fuel can be extended by $35 \%$ over the diesel and $120 \%$ over the gas turbine propulsion plants, respectively.

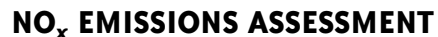

Fuel cells will have essentially zero $\mathrm{NO}_{x}$ emissions due to the electro-chemical process. Diesel engines, on the other hand, will produce $136 \mathrm{~kg} / \mathrm{h}$ at $24 \mathrm{knots}$ or $46 \mathrm{~kg} / \mathrm{h}$ at $16 \mathrm{knots}$, even assuming the Tier 3 IMO Annex VI emission standard compliance, which will not be effective until 2016. This $\mathrm{NO}_{x}$ can be essentially eliminated if the diesel engines are replaced by the fuel cell plants, leading to significant environmental pollution reduction benefits.

\section{Ship Hrrangement Implications}

Investigation was also carried to evaluate the ship arrangement implications of the proposed notional fuel cell-powered system by exploring different system dimensions and layouts, within the ship hull structure and engine room space constraints. The modularity of the IPS and fuel cell system was leveraged by taking advantage of 


\section{TABLE 11: Dimensions of Three Different SOFC Power Plant Configurations}

\begin{tabular}{lccc} 
& Length $(\mathbf{m})$ & Width $(\mathbf{m})$ & Height $(\mathbf{m})$ \\
\hline Configuration A (portstarboard) & 7.3 & 11 & 6.4 \\
\hline Configuration B (above-below) & 24.5 & 8.5 & 2.5 \\
\hline Configuration C (fore-aft) & 24.5 & 3.0 & 6.8
\end{tabular}

SOFC, solid oxide fuel cell.

flexibility in arranging electrical components. For the arrangement study, fixed pitch propellers with the same size as on the current LMSR were used, and advanced induction motors and motor drive systems were assumed, whose sizes were scaled from the all electric ship $\mathrm{DD}(\mathrm{X})$ and T-AKE with projected power density improvements incorporated.

With the same power density assumption for the SOFC, three different configurations were considered for the two main SOFC engines: port and starboard, above and below, fore and aft configurations. The dimensions of the configurations for the large SOFC power plants are listed in Table 11. It should be pointed out that building the SOFC engines as specified in Table 11 is beyond the state-of-the-art of the current fuel cell technology. The feasibility of constructing the SOFC engines in the future should be a topic of further investigation with inputs from the fuel cell design and manufacturing communities.

Machinery arrangement schematics were developed for three different configurations as shown in Figures 14-16. For each configuration, three different graphics are given in each figure: one for the power plants without the engine room constraints shown, and the other two pictures showing the power plants within the engine room viewing from the starboard and port side, respectively. Note that all the power plant and electrical components fit into a
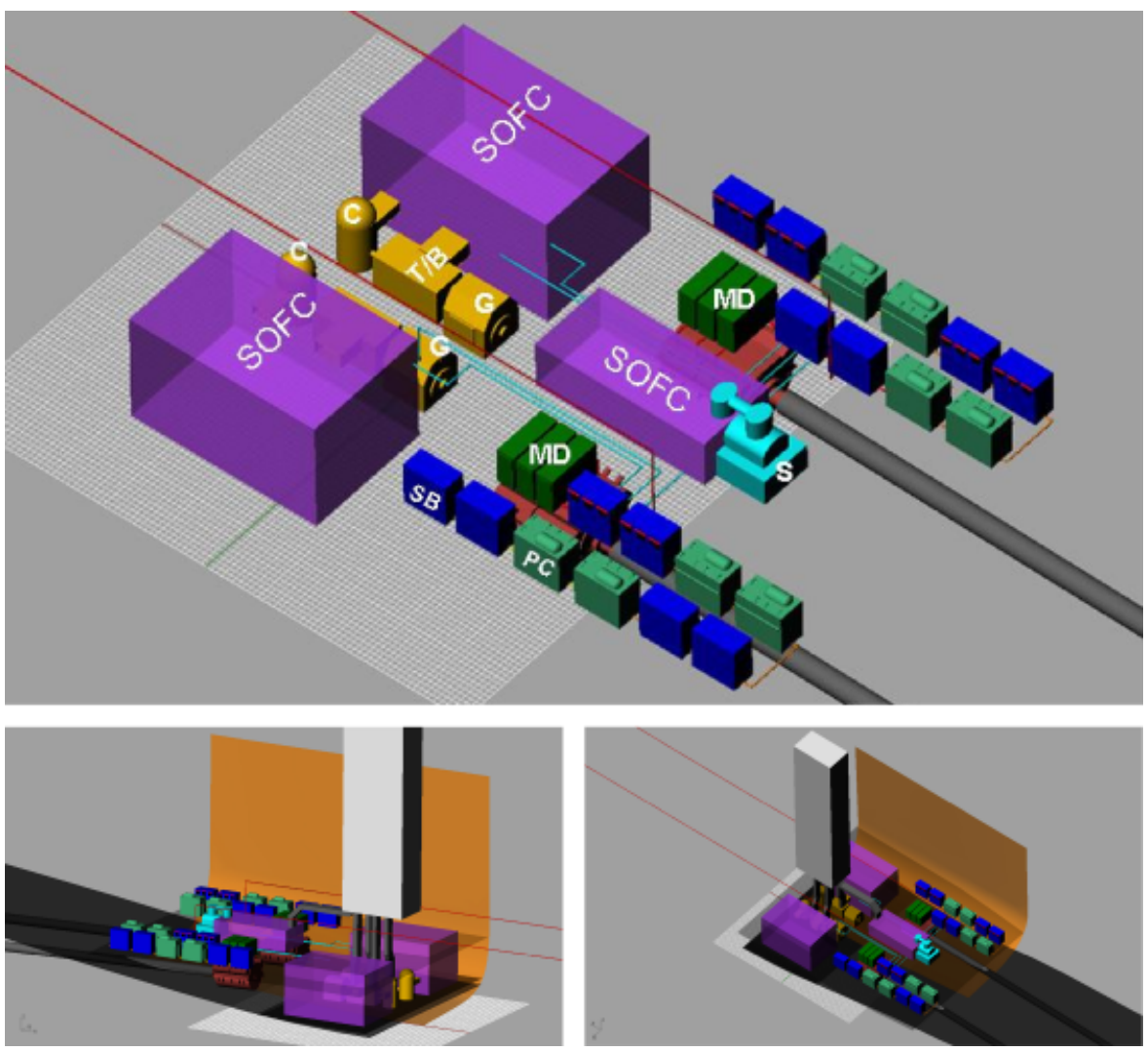

Figure 14: Machinery Arrangement of Configuration A 

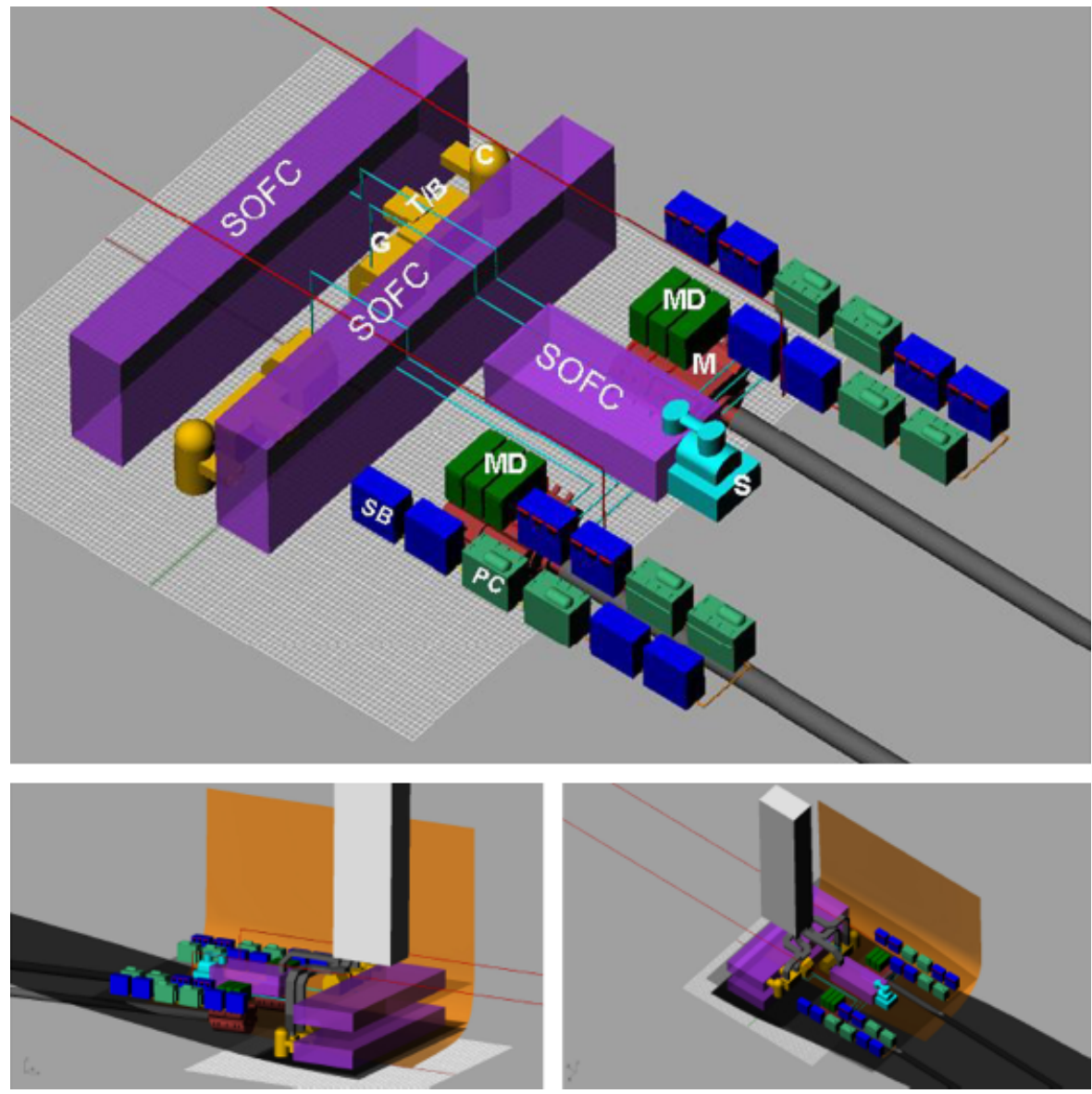

Figure 15: Machinery Arrangement of Configuration B (Refer to Figure 14 Discussion in Text for the Labels)

two-deck space. Other shipboard arrangement layouts are possible by further exploring the flexibility of the electrical system configuration.

For Figure 14, the top picture shows the machinery room arrangement without the hull; the two drawings at the bottom show the machinery room with hull and exhaust stack, viewed from starboard side (left) and port side. Legends on the figure are as follows: C, compressor; G, generator; $\mathrm{M}$, motor; $\mathrm{MD}$, motor drive; $\mathrm{PC}$, power converter; S, steam plant; SB, switch board; T/B, turbine and burner.

\section{Conclusion and Recommendations}

This study showed that a fuel cell-powered LMSR has tremendous potential in reducing fuel consumption and $\mathrm{NO}_{x}$ emissions. The associated economic and environmental benefits present a great incentive for naval and maritime industry to pursue fuel cell technology for the next generation green cargo ships. The extended range and improved endurance, together with the reduced fuel cost and environmental impact, also represent a unique opportunity for military sealift ships. Other features of the fuel cell-powered LMSR, such as modularity, distributed power generation, and flexible arrangements, could also facilitate ground-breaking innovations for ship design and arrangement optimization, as well as for ship construction.

The study also revealed that a minimum power density requirement of $45 \mathrm{~W} / \mathrm{L}$ of fuel cell system (or $40 \mathrm{~W} / \mathrm{L}$ if hybrid SOFC and GT system is used) has to be achieved in order to meet the 

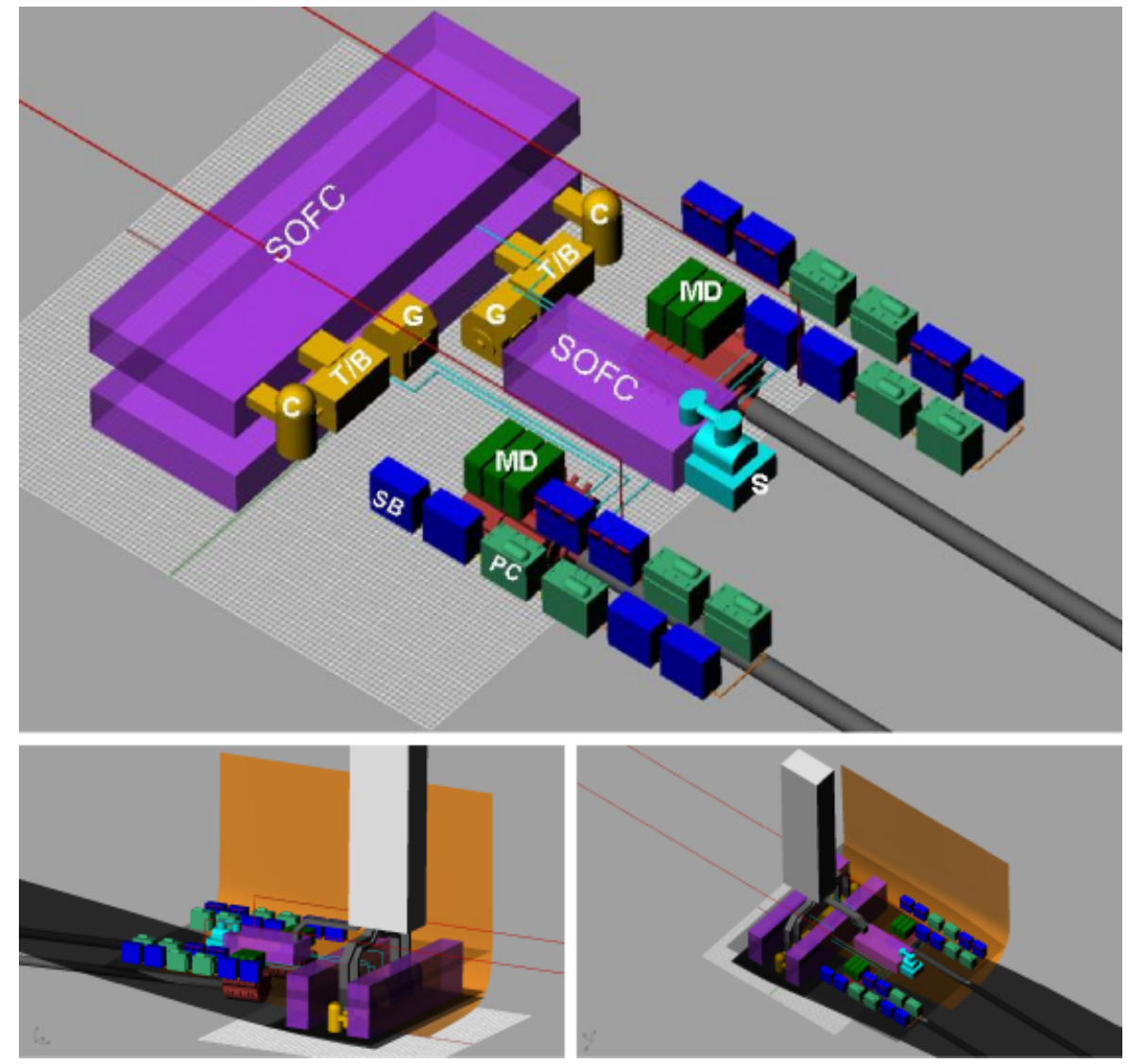

Figure 16: Machinery Arrangement of Configuration C (Refer to Figure 14 Discussion in Text for the Labels)

LMSR vessel power requirements under the existing hull form and machinery room constraints. Higher power density will provide more opportunities for cargo space expansion and machinery arrangement optimization. It should be pointed out that this level of power density for SOFC has not been achieved by the state-ofthe-art technology, even at a much lower power scale. Large technology gaps exist, and provide opportunities for development in all associated areas, including stack development, system integration, and control, just to mention a few.

This research also led to many open questions that warrant further investigation. The following efforts are recommended as follow-up activities to complement, substantiate, or extend this study:

Perform detailed weight/space analysis for all key electrical components.
Quantify other attributes of the fuel cellpowered LMSR in terms of thermal and acoustic properties, shock and vibration implications, survivability, reliability, maintainability, etc.

- Carry out the life cycle analysis (LCA) to determine the cost/benefit trade-offs for fuel cell-powered ships, taking into account acquisition cost, maintenance, and operational cost.

- Invest in long-term research and development on system integration of fuel cell-powered large vessels.

\section{Hcknowledgments}

Technical support and administrative help from Steve Ouimette, Jack Offutt, Tony Blair, and other members of CISD are greatly appreciated. Help from high school summer intern Josh 
Raanan on preliminary 3D model drawings is also appreciated.

The authors would also like to thank Ed House from NAVSEA Philadelphia and Mike Touma from Military Sealift Command Prepositioning and Sealift Programs for their inputs on the Office of Naval Research (ONR) fuel cell programs and on the engineering specifications of the vessels of interest, respectively. The work reported here was performed under the ONR-ASEE (American Society of Engineering Education) Summer Faculty Fellow Program, and the authors acknowledge the financial and administrative support from ONR, in particular the support and encouragement from ONR program director Ms. Kelly Cooper.

\section{References}

Allen, S., E. Ashey, D. Gore, J. Woerner, and M. Cervi, "Marine applications of fuel cells: a multi-agency research program," Naval Engineers Journal, Vol. 110, No. 1, pp. 93-106, 1998.

Collins, M., "Integrated power systems (IPS) for DDG 1000 and future navy ships," presentation at American Society of Naval Enģineers, October 2006.

Douglass, H. and D.S. Partos, "Evaluation of military utility of Navy Shipboard fuel cell program," CAN report, October 2003.

European Commission Transportation Research, "Mathapu: validation of a renewable methanol-based auxiliary power system for commercial vessels, 2009." Available at http://ec.europa.eu/research/transport/ projects/article_5113_en.html.

Fontell, E., T. Kivisaari, N. Christiansen, J.-G. Hansen, and J. Palsson, "Conceptual study of a $250 \mathrm{~kW}$ planar SOFC system for CHP application," Journal of Power Sources, Vol. 131, pp. 49-56, 2004.

FuelCell Energyy, "Ship service fuel cell demonstration," Final report prepared for US Navy, Office of Naval Research, May 2009.

Hammerschmidt, A., "Fuel cells propulsion of submarines," Proceedings of the Advanced Naval Propulsion Symposium, Arlinģton, VA, October 30-31, 2006.

Hoffman, D., "High efficiency, high power naval fuel cells," Presentation for Naval War College, June 2007.
Larminie, J. and A. Dicks, Fuel cell systems explained, 2nd ed., John Wiley \& Sons, New York, 2003.

Mueller, F., B. Tarroja, J. Maclay, F. Jabbari, J. Brouwer, and S. Samuelsen, "Design, simulation and control of a 100 megawatt-class solid oxide fuel cell gas turbine hybrid system," Proceedings of Fuel Cell 2008, Denver, CO, June 16-18, 2008.

Reenaas, M., "Solid oxide fuel cell combined with gas turbine versus diesel engine as auxiliary power producing unit onboard a passenger ferry: a comparative life cycle assessment and life cycle cost assessment," Master's thesis, Norwegian University of Science and Technology, 2005.

Sammes N., A. Smirnova and O. Gasylyev, eds., Fuel cell technologies: state and perspectives, NATO science series, Vol. 202, Springer, Berlin, 2005.

Singhal, S.C., and K. Kendall, eds., High temperature solid oxide fuel cells: fundamentals, design and applications, Elsevier, Amsterdam, 2002.

Stambouli, B. and E. Traversa, "Solid oxide fuel cells (SOFCs): a review of environmentally clean and efficient source of energy," Renewable and Sustainable Energy Reviews, Vol. 6, No. 5, pp. 433-455, October 2002.

Tsourapas, V., J. Sun, and A. Nickens, "Modeling and dynamics of an autothermal JP5 fuel reformer for marine fuel cell applications," International Journal of Energy, Vol. 33, pp. 300-310, 2008.

Tsourapas, V., J. Sun, and A. Stefanopoulou, "Modeling and dynamics of an integrated fuel cell stack and fuel process system with catalytic burner for marine applications," IASME Transactions, Vol. 2, No. 1, pp. 287-293, 2004.

Tsourapas, V., J. Sun, and A. Stefanopoulou, "Modeling and dynamics of a fuel cell combined heat power system for marine applications," Proceedings of 2005 American Control Conference, Portland, OR, June 2005, pp. 1993-1998.

US Military Sealift Command, "Enģineer's operation manual for USNS Bob Hope (T-AKR 300)," December 1998.

Zemships, Zero emission trips on the Alster, 2009. Available at http://www.zemships.eu/en/index.php.

\section{Huthor Biographies}

Jing Sun is a professor in the Department of Naval Architecture and Marine Engineering, 
University of Michigan(e-mail: jingsun@ umich.edu). She earned her Ph.D. degree from the University of Southern California in Electrical Engineering. Her research focuses on control and dynamic optimization of marine and automotive propulsion systems.

John Stebe is a naval architect in the Naval Acquisition Intern Program. He works in the Center for Innovation in Ship Design at the Naval Surface Warfare Center Carderock Division.

Colen Kennell has been employed as a naval architect by the Naval Sea Systems Command and the Naval Surface Warfare Center Carderock Division for 40 years. His primary work experiences are in early stage ship design, particularly on unconventional hull forms. He was the Project Naval Architect for T-AGOS 19 design, the US Navy's first large, open ocean capable SWATH ship and subsequent full scale trials. He served as the US Technical Director on the collaborative UK/US Trimaran Joint Trials project to build and test RV Triton, a $90 \mathrm{~m}$ trimaran. He developed Transport Factor methodology for analysis of high speed sealift ships. He is currently serving as Technical Director in the Center for Innovation in Ship Design. 